\title{
Os assassinatos imotivados e o advento do moderno debate crime-loucura
}

\section{The unmotivated murders and the advent of modern crime- insanity debate}

\section{Carlos Alberto Ribeiro Costa*}

Universidade Federal Fluminense Pólo Rio das Ostras - PURO/UFF, Rio das Ostras, Rio de Janeiro, Brasil

\begin{abstract}
RESUMO
O presente artigo visa abordar o papel do tópico "assassinatos imotivados" na constituição do movimento dúplice de "criminalização da loucura" e "patologização do crime", surgido entre o início e meados do século XIX: o "debate crime-loucura". Com tal enfoque, pretende-se explicitar algumas das matrizes mais primitivas desse "debate", em detrimento de seus desenvolvimentos mais comumente abordados, como a teoria moreliana da degeneração e a criminologia positivista de Cesare Lombroso. Esse escrito procura, ainda, contextualizar o surgimento desse "debate" como uma discussão moderna, advinda do aparecimento da ciência, na cena da cultura, do capitalismo e da noção de autoria do crime. Ao termo desse texto, aponta-se a alternativa lacaniana ante os impasses do debate crime-loucura: trata-se da aposta, ao mesmo tempo ética e política, na "conciliação necessária" entre as construções de saberes e a perspectiva da proteção de direitos.
\end{abstract}

Palavras-chave: assassinatos, imotivação, loucura, crime.

\begin{abstract}
This article aims to approach the role of the topic "unmotivated murders" in the constitution of the double movement of "criminalization of madness" and "pathologizing of crime", which appeared between the early and midnineteenth century: the "insanity-crime debate." This approach intends to clarify some of the most primitive bases of this "debate" over their developments more commonly tackled, as the morelian theory of degeneration and positivist criminology of Cesare Lombroso. This article also seeks to contextualize the emergence of this debate as a modern discussion, which arises out from the emergency of modern science, capitalism, and the notion of 'authorship of the crime' in modern culture. At the last part of this text, it is pointed out the Lacanian alternative ahead of the crime-madness debate dead-locks: it is the bet, ethical and political at same time, in the "necessary reconciliation" between knowledge constructions and the Protection of rights perspective.
\end{abstract}

Keywords: unmotivatione murders, madness, crime.

\section{Introdução}


França, crepúsculo do século XVIII. Na época do "massacre de setembro" ${ }^{1 "}$, uma pequena multidão armada franqueia as portas do Hospício de Bicêtre. Sob o "pretexto" de que a "antiga tirania" havia encarcerado ali "vítimas inocentes", esta aglomeração se entregara à tarefa de, de alojamento em alojamento, inquirir os internados, analisando, em cada caso, aqueles em que a "loucura era manifesta". Um dos reclusos, acorrentado, chamou a atenção dos revoltosos: "pleno de razão" ao explicar sua condição, ele lhes dirigia suas "amargas queixas". Como fora impossível reprovar qualquer "extravagância" em seus atos, os grilhões pareceram aos visitantes uma "injustiça revoltante". Clamando para que livrassem-no da "opressão", ele teve suas súplicas rapidamente atendidas. O "vigia" do hospício, que acompanhava toda cena, tendo "sabres dirigidos a seu peito", reclamava em vão sua própria experiência, falando de "alienados não-delirantes" que, ocasionalmente, eram tomados por um "furor cego".

Soltando-no aos gritos de "viva a república!", os "libertadores" não perceberam ter reanimado, com sua presença "ébria, barulhenta e armada", o "furor do alienado": tomando a espada das mãos de um dos estranhos ele "esgrima a direita e a esquerda, fazendo o sangue correr". Como resultado - diz o célebre alienista - "esta horda bárbara o traz de volta a seu alojamento, parecendo ceder, rugindo, à voz da justiça e da experiência" do alienista (Pinel, 1801, p. 160).

Esta história, cuja alegoria não deixa de evocar algo de 'mítico', fora talhada por Phillipe Pinel em seu Traité médico-philosophique sur l'alienation mentale, de 1801. Esse mito fundacional prenuncia como a nova "voz da justiça" transborda asilos e tribunais e ganha as ruas. Num processo que gradualmente se irradia pelo ocidente moderno, enquanto a psiquiatria passa a reclamar para si fins jurídicos, 0 direito estabelece objetivos "curativos", erigindo as bases do que com Harris (1993) e Carrara (1998) chamamos de "debate crime-loucura", movimento que se inaugura como um "conflito de competências" e que, pouco a pouco, converte-se em uma relação de "conflitos e confluências" entre essas disciplinas.

Ao tomar como contexto o movimento dúplice de "criminalização da loucura" e "patologização do crime", este artigo intenta explicitar algumas das matrizes mais primitivas deste "debate". Para que tal empresa possa ser atingida, privilegia-se, aqui, o caso dos assassinatos imotivados - ações loucas, cuja dinâmica punha em curto-circuito a mecânica utilitária dos "crimes por interesse". Vamos analisar de que maneira esses homicídios surgem como questão na modernidade - a partir do aparecimento da ciência moderna, na cena da cultura, do capitalismo e da noção de autoria do crime - ao exigirem explicações para além da percepção intuitivamente partilhada da loucura. A investigação dessas matrizes permitirá lançar 
luz sobre algumas das modernas formas de segregação e para o posterior vicejar da teoria da degeneração e do lombrosianismo.

\section{A senda percorrida por Phillipe Pinel}

O Traité médico-philosophique sur l'alienation mentale, livro de 1801, de Phillipe Pinel" coroa, no seio da cultura, o surgimento de um projeto, não menos revolucionário que seu contexto: um saber capaz de, para além da percepção imediatamente partilhada, iniciar a relação da loucura com o real. À psiquiatria nascente - que tinha em Pinel senão seu fundador, seu maior expoente - cabia, a partir do fenômeno, matéria-prima da percepção, agrupar os diferentes tipos de loucura, esvaziando da observação a "subjetividade do observador", e acomodando estes "tipos" em "classes, gêneros e espécies" (Bercherie, 1980, p. 31-2).

Essa sistematização, que encontra em Pinel seu esboço, instala a alienação não mais como elemento 'cosmológico', referido à 'tradição', mas como objeto 'científico' - o que implica sua imanência a um método e a um campo circunscrito de experimentação. Do mesmo modo que a ciência moderna: "os planetas não falam" - por serem "realidades completamente reduzidas à linguagem" (Lacan, 1954 [1955], p. 302), - o 'projeto' de sua captura num real científico, a loucura, tão eloquente no Elogio da loucura, de Erasmo de Roterdão (1509), começaria a tornar-se muda.

A nova 'captura', ainda que por ventura lançasse mão de antigos e toscos grilhões - como os mencionados por Pinel no excerto acima não se dava sem os aparatos, agora mais sofisticados, da 'nova disciplina'. Desenhava-se, pois, a ruptura entre a concepção socialmente partilhada da loucura e a nascente ciência da alienação. Um corte análogo fora reeditado no interior do próprio projeto pineliano.

A alienação, fragmento da realidade requerido pela psiquiatria em sua instalação na cena social, era definida, até então, a partir da chavemestra que era o conceito de "delírio". No sentido inverso daquele de "razão" - que implica que o sujeito, via cogito, era capaz de aceder à verdade - nas Meditações de Descartes (1641) a loucura figura no grupo das objeções levantadas pelo método da dúvida sob a forma do erro, da ilusão sensível:

E como eu poderia negar que estas mãos e este corpo sejam meus? Exceto, talvez, que eu me compare a esses dementes (...) que amiúde garantem que são reis, enquanto são bastante pobres; que estão trajados de ouro e púrpura, enquanto estão totalmente nus; ou imaginam ser vasos ou possuir um corpo de vidro. São dementes e eu não seria menos excêntrico se me 
pautasse por seus exemplos. (Descartes, 2000, p. 250, Grifo nosso).

O campo psiquiátrico, que tinha no delírio uma de suas concepçõeschave viu brotar, porém, no âmago de seu objeto, um ponto cego: loucuras na ausência de fenômeno delirante evidente. Tomada, até então, como sinônimo de loucura, tal evidência começa a deixar de ser o parâmetro para a constatação de alienação. A identificação da loucura não coincidirá mais com a percepção formatada pelo 'pool' cultural; a psiquiatria não fiará seu saber nesta concepção tradicionalmente partilhada da alienação.

A ausência de delírio prontamente identificável corroboraria o requerimento, por parte da psiquiatra, de um mandato social para exercer sua especialidade; caberia, agora, apenas ao psiquiatra 0 poder para detectar seguramente a loucura. Tal mandato adquiriria ainda mais legitimidade à medida que, à "mania sem delírio", Pinel atrela um "furor" homicida cuja imotivação", mesmo delirante, era patente. Tal peculiaridade seria por ele desenvolvida no tópico intitulado "A mania sem-delírio marcada por um furor cego", de seu Traité.

Conta-se, ali, a história de um homem, "outrora dedicado à arte mecânica" (Pinel, 1801, p. 157), que se encontrava internado em Bicêtre. Ocasionalmente tomado por uma "tendência sanguinária irresistível", este homem via-se impelido, quando de posse de objetos cortantes, à "sacrificar a primeira pessoa que visse" - o que chegara a colocar em risco a vida de sua "querida mulher". No Hospital, quadro semelhante se repetiria: o "vigia" do asilo, a quem o paciente louvava por sua "complacência e doçura", fora, desta vez, o alvo; noutra vez, ele talharia, ainda, seus próprios peito e braço. Em "pleno exercício da razão", "mesmo durante os acessos", esse homem não evidenciava "qualquer incoerência nas idéias". Em verdade, diz Pinel, - alienado "lúcido" horrorizava-se com a situação, censurando sua "tendência automática a atos de atrocidade" (Pinel, 1801, p. 157).

Noutro caso, também narrado no Traité, um homem "calmo", conhecido por sua "beneficência para com os desafortunados" atirara uma mulher num poço, após ter ouvido desta certos impropérios. Em consonância com tal desproporção, um grande montante de testemunhos atestava perante os tribunais que, "entregue" em sua infância "a todos seus caprichos", este homem "matava, de pronto, qualquer animal" - cão, cordeiro ou cavalo - que "Ihe causasse desgosto". Das "festas e assembléias" da cidade ele saia frequentemente "ensangüentado", por trocar socos com os demais. $\mathrm{Na}$ idade adulta, porém, o que remanescia de suas "tendências" eram apenas as "rixas monetárias". Julgado insano - mesmo na ausência de atividade delirante evidente - ele é enviado para "reclusão no hospício de alienados de Bicêtre". Agora, não só os "revolucionários", 
mas também os tribunais e os juristas rendiam-se à "justiça" e "experiência" do alienista (Pinel, 1801, p. 160).

\section{0 legado de Esquirol}

Grande precursor nas lutas pela legislação e institucionalização do campo psiquiátrico (Bercherie, 1981 p. 54; Foucault, 2001, p. 176; Harris 1993, p. 123), Esquirol majorará a dimensão moral da psiquiatria ao afirmar que "as paixões e o crime que armam a mão homicida não fogem de meu objeto" (Esquirol, 1838, p. 94). O discípulo de Pinel reencontra, deste modo, em sua cartola, o coelho da desordem que, em tese, deveria ter sido separado do objeto científico. Ampliando o "furor cego" descrito por seu mestre, ele o estende à quase todas as afecções das quais o psiquiatra, em seu ofício, viria se ocupar.

Os alienados atentam contra a vida de seus semelhantes; uns, tornados muito suscetíveis, muito irritáveis num acesso de cólera, batem, matam as pessoas que os contrariam ou que eles crêem os contrariar; eles matam as pessoas a quem tomam, a torto e a direito, por inimigos de luta, de quem é preciso que eles se defendam ou se vinguem. Outros, enganados pelas ilusões dos sentidos ou por alucinações, obedecem à impulsão do delírio. Alguns matam, motivam sua tenebrosa determinação, racionalizam suas ações, e tem consciência do mal que cometem. Outros são instrumentos cegos de uma impulsão involuntária, instintiva que Ihes impulsiona ao assassinato. Enfim, observa-se idiotas que, por falta de desenvolvimento da inteligência, na ignorância do mal como do bem, matam por imitação (Esquirol, 1838, p. 94).

Desde então, não apenas o homicídio louco, delirantemente orientado ou não, não poderia prescindir do método e do olhar do psiquiatra para ser efetivamente identificado, mas, também, todas as formas de loucura trariam, em si, o assassinato como uma virtualidade. Encontra-se, assim, na generalização de Esquirol, rudimentos de um debate que ganharia, paulatinamente, os tribunais, a mídia e a literatura. Este debate, moderno, em que loucura e crime se atrelam, desvelava a ambição social e política da psiquiatria.

Se a loucura ganhava, desde o século XIX, esta virtualidade homicida, tal processo seria impulsionado pela revolução trazida pelas "loucuras parciais". Enquanto na Inglaterra - onde esta discussão se dava em paralelo à França - Prichard cunhava o termo "loucura moral 3", Esquirol, contrastava a "tendência automática a atos de atrocidade" a "função sintética do eu" e ao imperativo de 
ordem da sociedade pós-revolução. De sua pena sairia a controversa entidade das "monomanias", afecções marcadas por uma "lesão parcial da inteligência, dos afetos e da vontade" (Esquirol, 1838, p. 1).

Com tal termo - cuja inadequação não escapara a Esquirol - visavase não à importação da categoria pineliana, mas, sim, empreender um esforço para separar "mania" e "loucura parcial": se na mania "todo entendimento é embaraçado", na monomania, "o entendimento é são, às vezes mesmo mais ativo que lúcido"; se na primeira "todo ser intelectual e moral está pervertido, todas as ações desordenadas", na segunda "a perversão do ato é parcial, circunscrito como o extravio da ação" (Esquirol, 1838, p. 5). Sustentando tais diferenças, Esquirol asseverará que a "mania sem delírio", curiosamente, não é uma mania, pois "quase todos os fatos de mania sem delírio lembrados pelos doutores [Pinel e Foderé] pertencem à monomania ou a lipemania (...) as impulsões irresistíveis apresentam todos os sinais de uma paixão chegada até o delírio (Esquirol, 1938, p. 96).

Se a "mania sem delírio", cunhada por Pinel, desaparece diluída na classe das monomanias, a "tendência automática a atos de atrocidade" e o "furor cego", descritas por ele, encontram, na famigerada classe esquiroliana das "monomanias homicidas", um lugar de destaque na nosologia psiquiátrica: "Há outros monomaníacos que matam por uma impulsão instintiva. (...) sem consciência, sem paixão, sem delírio, sem motivos; eles matam por um impulso cego, instantâneo, independente de sua vontade; eles estão num acesso de monomania sem delírio" (Esquirol, 1838, p. 98). A "cura" - a ser entendida como redução dos sintomas mórbidos -, raramente se seguia à realização daquelas impulsões homicidas e "estranhas mesmo ao delírio habitual" (Esquirol, 1838, p. 104). Todavia, como a experiência clínica de Esquirol levara a constatar, não raro os enfermos experimentavam, ao efetivar a insólita ação, certo apaziguamento em seu estado de "agitação" e "angústia".

Dentro desta lógica, vários foram os casos tornados célebres na época, como aqueles resgatados por Michel Foucault: Pierre Rivière; Léger, Papavoine e Henriette Cornier (examinados por J. E. Georget em 1825 e 1826); a mulher de Selestát (lido por C. H. Marc ${ }^{4}$ em 1832). Não por acaso Foucault, em 1975, consideraria essas histórias e seus desdobramentos psiquiátrico-jurídicos como "fundadores da psiquiatria criminal" (Foucault, 2001, p. 138).

Este tipo de casos, por seu caráter grotesco e grande repercussão na mídia, serviram de outdoor para propagar não apenas a noção de monomania, mas, também, dos assassinatos imotivados na loucura e da necessidade de um aporte científico ao problema.

Estava aberta a arena para que o debate moderno sobre a relação entre crime e loucura se colocasse em marcha. Assim, não apenas no 
interior do campo de debates da Psiquiatria, mas, também, na cena mais ampla da cultura, a possibilidade de uma forma de alienação que se caracterizava por um furor "cego", homicida, e na ausência de delírio, ganharia as manchetes de jornal assim como traria reverberações na literatura daquele tempo. Ao lado do recém aparecido gênero policial, autores como Dostoievski ${ }^{5}$, Lautreamont ${ }^{6}$ e $\mathrm{Poe}^{7}$, fizeram do binômio crime-loucura fonte de histórias não menos extraordinárias que o assunto na qual buscaram sua inspiração.

$\mathrm{Se}$, no que tange às artes e à mídia de massa estas reverberações se fizeram sentir, para os juristas as repercussões deste debate foram ambíguas. De um lado eles eram direta e negativamente afetados por tais desenvolvimentos: era posto 'em xeque' sua capacidade de julgar casos em que indícios de loucura se faziam presentes. Por outro lado, esta discussão ia ao encontro de evoluções no próprio campo do direito, que via nas noções de "livre-arbítrio" e "responsabilidade" construtos metafísicos e contrários ao espírito científico da época.

Em verdade, mais que uma imposição externa à sua disciplina, muitos juristas viam no debate crime-loucura a oportunidade para acelerar as reformas que, no que concerne aos fundamentos modernos do direito, faziam-se não só urgentes, mas já em marcha. Havia, logo, nesse direito que se moderniza, o aporte a ideais e instrumentos advindos da "nova ciência". Não seria este, todavia, o único momento em que teorias explicativas - e dispositivos alternativos - formatariam práticas peculiares, inclusive jurídicas, no que concerne a loucura.

\section{Crime e loucura no direito penal moderno: uma objeção?}

Disséramos, ao introduzir a problemática referente ao "debate crimeloucura", que se tratava, nesta, de uma discussão "moderna". Uma objeção, entretanto, pode ser levantada a respeito desta asserção: é que o mundo antigo não desconhecia a controvérsia envolvendo estes dois termos. Segundo Robinson (1998, p. 24), também na Grécia antiga "houve uma tensão entre o dever de expor e punir o culpado e aquelas teorias médicas, filosóficas e psicológicas que concerniam aos determinantes da conduta humana". Dito de outra forma, na antiguidade, onde talvez pela primeira vez as verdades eternas da religião e da tradição são substituídas pelo reconhecimento da vida política como fonte de obrigações, os questionamentos acerca do estatuto jurídico do louco já se impunham.

Mesmo antes das leis escritas - de $\operatorname{Drácon}^{8}$ [621 a. C.] e de Sólon ${ }^{9}$ [504-3 a. C.] - existia, no que concerne ao jurídico, a suposição de que algo, a dike (Justiça), subtraia o homem do bestial permitindo-o reconhecer "o justo, o desonesto e o correto" (Robinson, 1998, p. 134). Ora, é justamente esta capacidade de estar concernido, via 
entendimento e conformação, à lei que, para os gregos, resultava problemático na loucura. Se a razão, porta de acesso à dike faltava ao insano, a este restava um estatuto jurídico próximo ao do infante ou da besta selvagem; abria-se, então, campo para que, já no mundo antigo, se colocassem elementos do debate sob a inimputabilidade. Neste ponto, em que as peculiaridades do louco questionavam a pólis, literatura, filosofia e medicina requeriam espaço para tecer suas explicações.

Na Ilíada, por exemplo, como cita Robinson no primeiro capítulo de seu livro, Agamenon evoca "Loucura" para se desculpar com Aquiles por ter se apropriado do espólio de guerra do herói, a jovem escrava Briseis. Dirigindo-se ao 'quase invulnerável guerreiro' ele clama por um panteão de deuses afirmando:

Não fui eu quem o fiz, Zeus e Destino, e as Erínias que caminham na escuridão fizeram-me louco no dia em que tomei de Aquiles o prêmio a ele reservado. O que eu poderia fazer? Todas as coisas estão nas mãos do céu, e Loucura, a mais velha das filhas de Zeus vela os olhos dos homens para sua destruição. Delicadamente ela anda, não na terra sólida, mas sob as cabeças dos homens para feri-los ou enganá-los (Homero, n.d., citado por Robinson, 1998, p. 8).

Se já em Homero as considerações religiosas e mitológicas sobre o assunto alojavam um modo de apreender os móveis da conduta humana e dispunham o problema da imputação, a filosofia nascente forneceria um importante contraponto a esta perspectiva.

Este contraponto, não obstante, incidiria não sob a escusa do crime na loucura, mas, sim, na discrepância sob os móveis em jogo em tal isenção - escusa esta que encontraria reservas nos casos de homicídio. Deste modo, quando Platão em suas Leis demarca sua posição na discussão, ele o faz afirmando que, nos crimes impetrados por pessoas "em estado de loucura ou quando afetados por doença"

se isso for evidente para os juízes eleitos para julgarem a causa, sob apelo do criminoso ou de seu advogado, e ele for julgado como estando neste estado quando cometeu a ofensa, ele deve simplesmente pagar pelo dano que ele cometeu ao outro; mas ele deve ser isento de outras penalidades, a menos que tenha matado alguém e tenha suas mãos manchadas de sangue. Nesse caso ele deve ir para outra terra e país, e lá viver por um ano (Platão, n.d., citado por Robinson, 1998, p. 21).

Também a medicina - que florescia sob a égide de Hipócrates - viria aumentar o número de interpretações possíveis para os 'desvios' do 
louco. Expressando-se já em termos cerebrais, o pai da medicina concebeu uma causalidade que transcendia a própria loucura: "do cérebro, e apenas do cérebro, erguem-se nossos prazeres (...) tanto quanto nossas mágoas (...) são as mesmas coisas que nos fazem loucos (paraphronimos) ou delirantes... e [causam] atos contrários ao hábito" (Hipócrates, n.d, citado por Robinson, 1998, p. 32).

Se assim foi em Atenas, em Roma - onde a herança cultural grega e etrusca eram revisitadas desde o sucesso sem precedentes do Império - apresentavam-se, também, particularidades da loucura no que tange ao direito. Os furiosus, loucos com intervalos de sanidade, podiam, fora destes, ter contratos ou casamentos anulados, ser destituídos como paterfamílias - lugar delegado ao pai no controle da "unidade de produção" (Lopes, 2002, p. 41) que era a família romana -, sendo entregues à custódia do magistrado.

No mundo antigo, em que os loucos partilhavam seu lugar entre as referências ao infante e às bestas selvagens, categorias como nom compus mentis, fanaticus, idiotus e furiosus exprimiam a "sinceridade e refinamento da lei antiga nesta área" (Robinson, 1998, p. 678).

Havia, portanto, na Antiguidade: 1) certo reconhecimento da escusa da loucura em relação ao crime (ao menos no que tange aos delitos menos graves, vale dizer, que não envolviam assassinato); 2) saberes, no sentido mais amplo do termo, como a medicina, a literatura e a filosofia, que cunhavam teorias e explicações sobre este fenômeno; e, 3) certa permeabilidade do direito às peculiaridades do louco. Ante estes elementos estaríamos nos contradizendo ao afirmar que o debate crime-loucura é um advento 'moderno'?

A resposta a esta questão apenas pode ser negativa; embora houvesse, já, no direito antigo, um lugar diferenciado para o insano, a construção deste lugar era efetuada com base na percepção popular do que era a loucura; não havia, portanto, uma 'definição' do que se reconhecia como 'insanidade'. Contrariamente ao que ocorre a partir da modernidade, estes elementos não conferiam às discussões jurídicas subsídios para que se cogitasse acerca das "intenções do crime". Robinson, a este respeito, argumenta que parte dos motivos desta discrepância reside na "antiga concepção grega de natureza (physis)", também incorporada pelos romanos, de acordo com a qual era natural para o homem ser racional e viver em sociedade sob as regras da lei:

Se a definição da natureza humana era tão devastada pela doença ou destituída pelos deuses, a pessoa afligida estava por causa disso excluída da discussão. Ser uma besta selvagem era, como foi, deixar o genus [gênero] e ser localizado na parte da taxonomia para a qual a lei não tem alcance ou remédio. Por esse olhar, pouco importava se a causa se originara no Olimpo, no crânio ou no clima. (Robinson, 1998, p. 33). 
No mundo antigo a questão sobre os móveis do crime não podia se apresentar a um tribunal a ela sensível; julgava-se o ato em suas qualidades intrínsecas e não as de seu autor. Esta impossibilidade redobrava-se na medida em que o ato 'louco' encontrava-se como que "fora da natureza". Deste modo, as cortes antigas tomavam o crime ele mesmo como evidência da capacidade mental; vale dizer, sob a égide do equilíbrio na 'ordem das coisas', os danos causados pelo insano deveriam encontrar compensação e seus crimes punição.

Era preciso, ainda, um passo capital para que este estado de coisas se modificasse. Correlatos a uma transformação no conhecimento, nas estruturas sociais e no próprio conceito de homem, o advento da modernidade e da nova ciência são a condição sine qua non para que o debate crime-loucura efetivamente ganhasse corpo.

\section{0 crime e as penas na modernidade}

Enquanto floresciam o capitalismo e os estados nacionais, o iluminismo tornava populares as teorias naturais e deterministas da ação humana. O triunfo da razão científica explodia o $\operatorname{cosmos}^{10}$ sustentado pela tradição, preparando o campo para a vindoura revolução industrial. O cartesianismo e a noção de sujeito evocavam uma epistemologia de ideias claras, de raciocínios a serem explicitamente demonstrados. Não tardaria para que tais transformações atingissem o direito.

Neste campo surgia o entendimento, por volta do século XVII e XVIII, de que havia uma área de "não interesse da lei" (Robinson, 1998, p, 122), o que abria um hiato entre as leis jurídicas e as que regem a ordem das coisas - hiato este que não dispensava a referência ao 'espírito científico'. O direito natural moderno - ou jus-naturalismo emerge, pois, simultâneo à queda do 'homem-animal político aristotélico'. Desvinculando-se da esfera teológico-filosófica, o novo direito tende a ser "axiomático, dedutivista, universal, impessoal, abstrato. Já não apela à autoridade eclesiástica como fonte de legitimação" (Lopes, 2002, p. 218). Imprime-se um corte que desaloja as antigas autoridades - vividas agora como heterônomas; instaura-se uma trajetória que se desenha desde a possibilidade de acesso de "qualquer um" à racionalidade das leis, até as exigências que exigiam, desse sujeito 'anônimo', uma formação competente:

O direito natural moderno quer ser um direito do senso comum, pelo qual todos podem chegar às máximas jurídicas. É, no entanto, dominado por saberes competentes, pela mesma razão que a geometria, sendo evidente uma vez aprendida, não 
é evidente para uma mente não suficientemente treinada, como diz Locke (Lopes, 2002, p. 219).

Na esfera das punições, o Antigo Regime, e suas práticas centradas no que Foucault chama de manifestação "excessiva" cede lugar, pouco a pouco, a uma nova economia da punição. Segundo Foucault (2001, p. 143), esta "manifestação excessiva" consistia em: 1) reapresentar, no castigo, uma analogia com o crime cometido; 2) uma "revanche" do soberano, cujo lugar por ele ocupado confundiase com a lei; 3) uma tentativa de anular o ato transgressor ante a esmagadora potência coercitiva do soberano. Como estas manifestações objetivavam "apagar o ato", não havia, no Antigo Regime, a possibilidade de que se questionasse a respeito seja da mecânica do ato seja, ainda, sobre a natureza do transgressor.

Ora, tratava-se, antes, nas penalidades, de evidenciar a desproporção existente entre os lugares do soberano e do criminoso, na modernidade imperativo se fazia punir o crime numa 'medida exata', sem comportar excessos, simplesmente para que a transgressão não recomeçasse. A economia 'moderna' dos suplícios deveria coadunar-se à lógica, ao mesmo tempo capitalista e científica, de "majorar o poder, diminuir seus custos e integrar os mecanismos de produção" (Foucault, 2001, p. 108).

Algo semelhante ocorria nas codificações modernas das leis: 0 conjunto de normas era erigido de forma a tolher não apenas a transgressão do réu, mas, também, os excessos do juiz e do soberano; deste modo também os últimos deviam passar pelo crivo da nova razão. É assim que os códigos, sob influência do utilitarismo de Beccaria ${ }^{11}$ e dos imperativos morais de Kant, fazem do sujeito racional seu corolário.

Começa a ganhar corpo, também no campo penal, o processo de cifragem que procede absorvendo o singular no universal, processo este que, na esfera científico-jurídica, instaura dois novos objetos: o 'crime real' e o 'criminoso'. Mergulha-se na era do que Miller (2004) chamou de o "homem sem qualidades" ${ }^{12 ", ~ d o ~ s u j e i t o ~ q u a n t i f i c a ́ v e l, ~}$ redutível à cifra; faz-se possível uma operação de segregação da singularidade não pela simples exclusão, como outrora, mas, sim, por meio de uma inclusão que, ao universalizar, aparta:

Numa civilização em que o ideal individualista foi alçado a um grau de afirmação até então desconhecido, os indivíduos descobrem-se tendendo para um estado em que pensam, sentem, fazem e amam exatamente as mesmas coisas nas mesmas horas, em porções do espaço estritamente equivalentes (Lacan, 1998, p. 146). 
Nesta série de rupturas, o crime ganha outro estatuto: "desde então é preciso que haja seus motivos, com os móveis do crime; esses motivos e esses móveis devem ser compreensíveis, e compreensíveis para todos" (Lacan, 1998, p. 140). A atenção desliza, pois, do registro antigo do ato em si, para sua relação, a ser quantificada, com a "razão ou interesse do crime". Constitui-se um "real" para o crime, visa-se apreender os princípios de seu "aparecimento, sua repetição, sua inteligibilidade natural" (Foucault, 2001, p. 110). Nesta 'mudança de registro' a transgressão torna-se punível em virtude da superposição da mecânica da ação à racionalidade do sujeito, cônscio e motivado ao ato.

Destarte, se de um lado se asseverava que as provas do crime e a mecânica do ato criminoso são acessíveis a todos - porque imanentes ao sujeito racional - por outro, a necessidade de obter "uma mente suficientemente treinada" dispunha a necessidade das disciplinas específicas. É para este novo direito - e para suas tecnologias punitivas - que se apresenta, no final do século XVIII, 0 problema dos 'assassinatos imotivados'.

\section{Os assassinatos imotivados: "conflito de competências" ou "conflitos e confluências"?}

Ao passo que se consolidava o processo de desmistificação da loucura e que ganhava força a noção de "liberdade individual" - concepção "burguesa", segundo Lacan (1933, p. 375) - tornara-se desumano punir alguém por um feito que se efetivava à revelia de sua razão e vontade. É este o contexto em que se ergue o movimento, dito 'humanista', que subtrai os loucos das chamadas "casas de correção" e que, posteriormente, institui o célebre artigo 64 do código penal francês de 1832, segundo o qual "não há crime nem delito quando o réu estava em estado de demência no momento da ação, ou quando foi coagido por uma força a qual não pôde resistir". A princípio, tais julgamentos não eram problemáticos; entendia-se que "os jurados de bom senso e percepção normal podiam pesar as evidências neste tipo de casos tão bem quanto em uma miríade de outras ações civis e criminais" (Robinson, 1998, p. 120).

Como visto, porém, nos casos "fundadores" da psiquiatria criminal, os assassinatos imotivados foram arautos na alteração desta realidade: ante -homicídios cuja loucura do ato contrastava com a ausência de delírio prontamente identificável, cabia apenas à 'nova ciência' psiquiátrica requerer, para si - inclusive nos tribunais - seu mandato social perante o assunto.

Se, no início do século XIX, emergiam grandes dificuldades para o julgamento de réus insanos, este movimento teria como saldo a criação, no interior de uma zona até então pertencente ao direito, da 
demanda pelo especialista. Se na época dos "witch trials"13 a figura do expert já se tornara presente para efeito de identificação das marcas imateriais do fenômeno de possessão, "quando os vestígios do pactum implicitum ${ }^{14}$ foram finalmente expurgados, as cortes deveriam reservar ainda um lugar para outros especialistas presumidos terem acesso aos sombrios mistérios da mente e do espírito" (Robinson, 1998, p. 122).

Agora, desde os casos de "delírios parciais" e dos "assassinatos" ditos "imotivados", "não mais as cortes sentariam confortáveis precisando decidir se um réu era delirante no tempo da ofensa. Não mais as percepções ordinárias do homem da rua proveria evidência conclusiva da sanidade do autor" (Robinson, 1998, p. 151).

Com efeito, se este conflito mostra-se, num primeiro instante, como uma guerra de competências, num segundo momento a tensão entre justiça e medicina irá alojar uma área de confluência e cooperação. Assim, na modernidade, o recurso aos experts é experimentado pelo direito "primeiro com aversão, logo como matéria de fato e, finalmente, com avidez" (Robinson, 1993, p. 128). Por conseguinte, tanto impõe-se o curto-circuito na mecânica utilitarista dos "interesses do crime" quanto abre-se a via pela qual a hesitação inicial do ordenamento jurídico se transforma em ávida demanda à análise científica:

Seguro de si e até implacável, desde que apareça sua motivação utilitária (...), o pensamento dos penalogistas hesita diante do crime em que surgem instintos cuja natureza escapa ao registro utilitarista no qual se manifesta o pensamento de Bentham. (Lacan, 1998, p. 136)

Apresenta-se, assim, um dilema: se, conforme o artigo 64 não se encontra racionalidade no ato, o sujeito que lhe é correlato não é claramente louco. A justiça, em pane, convoca a análise científica. Paradoxalmente, como pontuara Foucault (2001, p. 147), ao mesmo tempo em que convoca, num alhures, a análise científica, o direito não poderá "reinscrever" esta análise, proveniente do campo de saber psiquiátrico, no interior de sua racionalidade. Neste estranho amálgama - em que o 'conflito de competência' transforma-se em 'conflito e confluência' - a justiça demandará à ciência não apenas a identificação, mas, também - como que 'por contrabando' - a "profilaxia", vale dizer, a construção de ferramentas para a detecção e prevenção do crime.

Este processo, deveras complexo, se expandirá, ainda, à medida que a perspectiva positivista, ao longo do século XIX, ganha terreno. Sob a égide do pensamento que não apenas critica, mas que visa a extirpar os pressupostos metafísicos das várias instituições humanas, 
o positivismo atinge, também em meados do século XIX, o campo do direito:

Se a ciência medieval se confundia com a especulação gramaticada, e se a ciência moderna se associava à geometrização do mundo, os juristas haviam, a seu tempo, incorporado aquelas concepções de ciência. Porque não 0 fariam também no advento da ciência positiva? (Lopes, 2002, p. 223).

Urgente era o abandono das bases morais e metafísicas e o construir de melhores formas de 'defesa social'. Ante a urbanização e a criminalidade "crescentes", o "fracasso" das prisões no papel de recuperar 0 transgressor era evidente. Enquanto exigiam-se inovações, a própria noção de "justiça" restava problemática diante do projeto de uma administração social científica, projeto este partilhado por médicos e juristas:

Esta nova geração de especialistas sócio-científicos duvidava das rígidas categorias estabelecidas pelo código penal e sugeria que considerações técnicas, e não morais, fossem utilizadas para favorecer um programa mais eficaz de administração social (Harris 1993, p. 24).

Com o espírito científico transmutado em cientificismo, abundavam analogias entre crime e doença. 0 sanitarismo ${ }^{15}$, entre medicina, política e direito, crescia como proposta de combate ao mal-estar social alojado pelo crime. A sociedade - como "organismo social" via-se ameaçada pelo "micróbio do criminoso". Como uma imagem simétrica e invertida de seu mestre Esquirol - que virtualizou, na loucura, o homicídio -, psiquiatras como Georget, explicitam a patologização do homicídio: "os assassinos são loucos, embora não evidenciem sinais de perturbação intelectual" (Georget, 1826, citado por Harris 1993, p. 18). Na ausência de uma etiologia unívoca da loucura a vida moderna passa a ser vista, ela também, como propiciadora do crime e do enlouquecimento. A população tornava-se, pouco a pouco, sinônimo de uma classe psíquica e moralmente degenerada.

Estava armada a cena para que desenvolvesse, em sua plenitude, o debate crime-loucura, em sua dupla vertente: "criminalização da doença" e "patologização do crime" (Carrara, 1993, p. 97); abre-se a senda para o que Lacan chamara de "concepção sanitária da penalogia": num imperativo de defesa social em que qualquer referência ao campo ético mostra-se explodida, as classes dominantes encontram, na análise científica, 0 remédio para 0 
desconforto em punir os explorados e subjugar o louco, verdadeiro avatar da desordem:

como o grupo que faz a lei não está, por razões sociais, completamente seguro da justiça dos fundamentos de seu poder, ele se remete a um humanitarismo em que se exprimem igualmente a revolta dos explorados e a consciência dos exploradores, para os quais a noção de castigo tornou-se igualmente insuportável. A antinomia ideológica reflete, aqui como em outros aspectos, o mal-estar social. Ela agora busca sua solução numa formulação científica do problema, isto é, numa análise psiquiátrica do criminoso a que deve reportar-se, após examinar todas as medidas de prevenção contra o crime e de proteção contra sua recidiva, o que podemos designar concepção sanitária da penalogia (Lacan, 1998, p. 139).

\section{Conclusão}

Ao longo de todo este artigo, intentou-se apreender o lugar e a função que os assassinatos imotivados tiveram para o surgimento e desenvolvimento do dúplice processo, cujos desdobramentos são tangíveis mesmo hoje, de "criminalização da loucura" e "patologização do crime". Com efeito, este processo, o "debate crimeloucura", se consolidaria, entre meados do século XIX e início do século $X X$, através de duas doutrinas que tiveram, ao longo deste período, gigantesca influência no pensar ocidental sobre o tema: a "teoria da degeneração" - de Morel - e a "Antropologia criminal", de Lombroso. Mesmo antes deste cume, porém, pretendeu-se explicitar como, entre Psiquiatria e Direito, as raízes deste debate já haviam sido colocadas. Na passagem de "conflitos de competência" para "conflitos e confluências" - posto que tensões entre esses dois campos, embora menos opositivas, ainda se mantém -, dispositivos como "perícias", "exames criminológicos" e instituições totais como os "manicômio judiciários" vieram à luz.

Em textos sobre a criminologia nos anos 50, Lacan se interroga acerca das formas de inserção nessa rede de tensões daqueles que se aventuram no debate crime-loucura. Verdadeiro turning point, propõe ele contribuir menos "ao estudo da delinqüência (...) do que para estabelecer seus limites legítimos" (Lacan, 1998, pp. 127-128), posição que se desdobra em importantes coordenadas. O limite ético: a não confusão entre a ação do analista e a "ação policial" - postura legalista, expiatória ou punitiva. A incompletude simbólica, inerente à relação sujeito-saber, inclusive o científico: se, por vezes, a expertise, reifica e "desumaniza", "nenhuma ciência das condutas pode reduzir a particularidade do devir humano" (Lacan, 1998, p. 
131). A aposta ética-política, a responsabilidade do analista ante a tensão entre ciência e justiça e suas repercussões para o corpo social. Nesse ponto, ele ressalta, já nos anos 50 , a importância da proteção dos direitos na inserção do analista no campo criminológico, posto que é preciso haver "a conciliação necessária entre os direitos do indivíduo" e "os progressos abertos pela ciência" (Lacan, 1998, p. 130).

\section{Referências}

Beccaria, C.(1997). Dos delitos e das penas. São Paulo, Editora Revista dos Tribunais.

Bercherie, P. (1989). Os fundamentos da clínica: história e estrutura do saber psiquiátrico. Rio de janeiro, Jorge Zahar Editor.

Carrara S. (1998). Crime e loucura: o aparecimento do manicômio judiciário na passagem do século. Rio de Janeiro: EdUERJ.

Descartes, R. (2000). "Meditações", In Pensadores. Editora Nova Cultural.

Dostoievski, F. (2010). Crime e castigo. V. I \& II., São Paulo: Editora Abril. (Trabalho original publicado em 1866)

Erasmo de Rotterdão. (1988). Elogio da Loucura. In Os Pensadores. São Paulo: Nova Cultural,.

Esquirol, J. E. D. (1838). Des maladies mentales considérés sous les rapports medical, hygiénique et médico-légal. vol. I \& II, Paris: J.-B. Baillière.

Foucault, M. (2001). Os anormais. São Paulo: Martins fontes. (Trabalho original pulicado em 1975)

Harris, R. (1993). Assassinato e loucura: medicina, leis e sociedade no fin-de-siècle. Rio de Janeiro: Rocco.

Koyré, A. (1979). Do mundo fechado ao universo infinito. São Paulo: Editora da Universidade de São Paulo. (Trabalho original publicado em 1957)

Lacan, J. (1933). Motivos do crime paranóico: o crime das irmãs Papin. In Da psicose paranóica em suas relações com a personalidade. Rio de Janeiro, Forense-Universitária. (Trabalho original publicado em 1932)

Lacan, J. (1998) "Introdução teórica às funções da psicanálise em criminologia". In Escritos. Rio de Janeiro, Jorge Zahar. (Trabalho original em 1950)

Lautreamont (2005). Os cantos de Maldoror. São Paulo: Editora Iluminuras. (Trabalho original publicado em 1868/1869)

Lopes J. R. L. (2002). O direito na história: Lições introdutórias. Editora Max Limonad, São Paulo, 2002.

Miller, J. A. (2004). "A época do homem sem qualidades" In Opção Lacaniana on line. 
Pinel, P. (1801). Traité médico-philosophique sur l'áliénation mentale, ou La manie. Paris.

Poe, E. A. (1987). Histórias extraordinárias. Rio de Janeiro: Ed. Globo S.A.

\section{Endereço para correspondência \\ Carlos Alberto Ribeiro Costa}

Universidade Federal Fluminense

Rua Recife, s/n, Jardim Bela Vista, CEP 28890-000, Rio das Ostras, RJ - Brasil

Endereço eletrônico: carloscosta.psi@gmail.com

Recebido em: 12/06/2012

Reformulado em: 21/01/2014

Aceito para publicação em: 05/02/2014

\section{Notas}

* Professor Adjunto do Departamento de Psicologia da Universidade Federal Fluminense, Campus de Rio das Ostras, Rio de Janeiro, Brasil; Doutor em Teoria Psicanalítica pela Universidade Federal do Rio de Janeiro.

1 Nomeia-se, com esta expressão, uma série de execuções em massa que se desenrolaram em setembro de 1792 por toda França. Neste sangrento episódio, no qual em 5 dias foram executadas cerca de 1400 pessoas, os revolucionários invadiam prisões e asilos e instauravam tribunais com o intuito de julgarem, eles mesmos, os criminosos. A "pena capital" foi muitas vezes aplicada. Este episódio, às vésperas da revolução, teve, como seu cume, a prisão do Rei Luís XVI.

${ }^{2} \mathrm{O}$ uso deste termo implica em sua não redução ao compreensível, ou seja, àquilo que se constitui por referência ao sentido imediata e socialmente partilhado.

3 Em A Treatise on insanity ond others disorders of mind (1835), Prichard, escrevera, a partir da "mania sem delírio" de Pinel, sobre a "loucura moral", "forma de desarranjo mental no qual as faculdades intelectuais [estão ilesas], enquanto a desordem é manifestada no estado de sentimentos, temperamento, ou hábitos ... os princípios morais da mente" (Prichard, ANO, citado por Robinson 1996, p. 161).

4 Jean Etienne Georget (1795-1828) e Charles Henri Marc (1771-1841), médicos psiquiatras, foram dois dos principais discípulos de Esquirol.

${ }^{5}$ Em Crime e castigo, o autor faz de seu anti-herói Rakolnikov, um monomaníaco (DOSTOIÉVSKI, p. 376).

${ }^{6}$ Em Cantos de Maldoror, pergunta-se o personagem: "É um delírio de minha razão doente, um instinto secreto (...) semelhante àquele da águia descendo sobre a presa, que me impele a cometer o crime? (Lautreamont, 2005).

7 Contos como $O$ coração denunciador, William Wilson e etc denotam homicídios relacionados ao enlouquecimento.

8 Drácon, membro da assembléia dos nobres de Atenas fora encarregado, em tempos de guerra, de constituir um código de leis escritas. Seu rigor renderia, à posteridade, o termo "draconiano" como sinônimo de "desumano" e "excessivo".

${ }^{9}$ Sólon, considerado um dos sete sábios da Grécia antiga. Segundo Lopes (2002, p. 34),"As leis de Sólon eram ensinadas como poemas, de modo que todo ateniense bem educado terminava por conhecer sua tradição político-jurídica comum".

${ }^{10}$ Koyré (1979), em Do mundo fechado ao universo infinito (1957), chama atenção para esta "radicalíssima revolução" em que o homem não apenas perdera "seu lugar no mundo", mas perdera "o próprio mundo em que vivia e sobre o qual pensava, e teve que substituir não só seus conceitos e atributos fundamentais, mas até mesmo o quadro de referência de seu pensamento" (idem, p. 13). 
11 Cesare Beccaria (1738-1793), em Dos delitos e das penas (Beccaria, 1997, enunciou, pela primeira vez, que a finalidade das penas é "impedir que o réu cause novos danos a seus concidadãos e demover os outros de agir desse modo" (idem, p. 52). Na aplicação das penas, essas deveriam causar "a impressão mais eficaz e duradoura no espírito dos homens, e a menos tormentosa no corpo do réu" (idem, p. 52).

${ }^{12}$ Com tal termo tomado do "profético escritor Robert Musil", Miller assevera que "o homem sem qualidades é aquele cujo destino é o de não ter nenhuma outra qualidade senão a de ser marcado pelo $1 \mathrm{e}$, deste modo, poder entrar na quantidade" (Miller, 2004, p. 3). Para Miller, "Tornar-se unidade contável e comparável é a tradução efetiva do domínio contemporâneo do significante-mestre sob sua forma mais pura, mais estúpida: o número 1 " (idem, p. 2).

13 Julgamentos de bruxas que varreram o mundo entre os séculos XIV e XVII.

${ }^{14}$ Num mundo em que as leis herdadas do mundo antigo eram reinterpretadas a partir do binômio crime-pecado, os acusados de tal pacto eram tidos, não como vítimas, mas, sim, como ansiosos cooperadores.

${ }_{15}$ Estratégias de 'controle' da população, tecidas, mormente, sob a égide econômica. 